\title{
Continuous Water-Quality and Suspended-Sediment Transport Monitoring in the San Francisco Bay, California, Water Years 2011-13
}

The U.S. Geological Survey (USGS) monitors water quality and suspended-sediment transport in the San Francisco Bay. The San Francisco Bay area is home to millions of people, and the bay teems with both resident and migratory wildlife, plants, and fish. Fresh water mixes with salt water in the bay, which is subject both to riverine and marine (tides, waves, influx of salt water) influences. To understand this environment, the USGS, along with its partners (see "Acknowledgements"), has been monitoring the bay's waters continuously since 1988 . Several water-quality variables are of particular importance to State and Federal resource managers and are monitored at key locations throughout the bay (fig. 1). Salinity, which indicates the relative mixing of fresh and ocean waters in the bay, is derived from specific conductance measurements. Water temperature, along with salinity, affects the density of water, which causes gravity driven circulation patterns and stratification in the water column. Turbidity is measured using light-scattering from suspended solids in water, and is used as a surrogate for suspended-sediment concentration (SSC). Suspended sediment often carries adsorbed contaminants; attenuates sunlight in the water column; deposits on tidal marsh and intertidal mudflats, which can help sustain these habitats as sea level rises; and deposits in ports and shipping channels, which can necessitate dredging. Dissolved oxygen, which is essential to a healthy ecosystem, is a fundamental indicator of water quality, and its concentration is affected by water temperature, salinity, ecosystem metabolism, tidal currents, and wind. Tidal currents in the bay reverse four times a day, and wind direction and intensity typically change on a daily cycle: consequently, salinity, water temperature, suspendedsediment concentration, and dissolvedoxygen concentration vary spatially and temporally throughout the bay, and continuous measurements are needed to observe these changes. The purpose of this fact sheet is to inform the public and resource managers of the availability of these water-quality data.

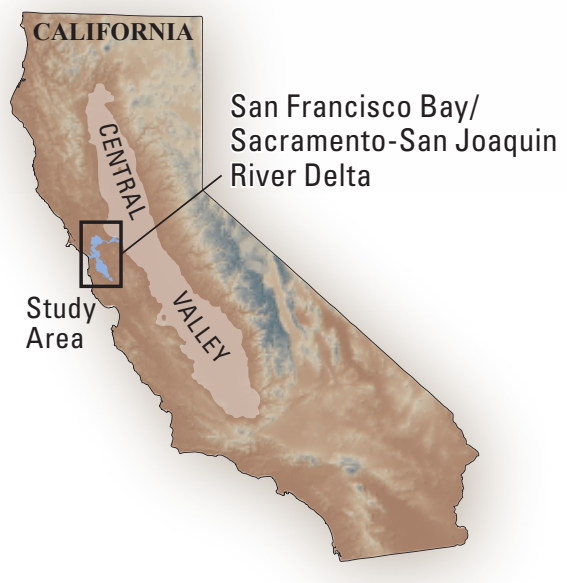

Figure 1. San Francisco Bay study area, California. 


\section{Program Overview}

Continuous water-quality measurements are, or have been, collected at several monitoring stations in the bay (fig. 1, table 1), as described at http://ca.water.usgs.gov/projects/ baydelta/. Instruments usually are deployed in the water by suspension from a stainless-steel cable that is anchored to the bottom (fig. 2). Instruments are equipped with a variety of sensors (explained later), and data are recorded every 15 minutes. Data are retrieved by using cellular telemetry (these data are available on the internet within 1 hour of measurement) or, for stations without telemetry, are downloaded during periodic site visits (provisional data are available on the internet within 2 weeks of the site visit). Biological growth, which can affect sensor readings, usually increases with time, and the affected data need to be revised or deleted. Every $2-5$ weeks (usually 3 weeks), each site is visited to clean and calibrate the instruments and, if needed, download data. Water samples are collected from the same depth as the sensor to calibrate the turbidity data to the suspended-sediment concentrations (SSC; fig. 3). For stations that compute water discharge and cross-sectionally averaged SSC, water samples are collected periodically at points across the channel by using the equaldischarge-increment method, and velocity is measured by

Table 1. Continuous water-quality monitoring stations, Suisun Bay, San Pablo Bay, and Central and South San Francisco Bays, California, October 1, 2010-September 30, 2013.

[Abbreviations: SF, San Francisco; SpC, specific conductance; T, water temperature; SSC, suspended-sediment concentration; DO, dissolved oxygen; Q, water discharge; SSF, suspended-sediment flux; NWIS, National Water Inventory System; - , not applicable]

\begin{tabular}{|c|c|c|c|}
\hline Water-quality parameter & $\begin{array}{l}\text { Measurement } \\
\text { location }\end{array}$ & Period of record & Remarks \\
\hline \multicolumn{4}{|c|}{ Alviso Slough near Alviso, 11169750} \\
\hline $\mathrm{SpC}, \mathrm{T}$, turbidity, SSC, DO & Near-bottom & 2010-present & - \\
\hline $\mathrm{SSC}$ & Cross-section & 2010-present & - \\
\hline Q, SSF & Cross-section & 2010-present & Q and SSF data are not yet available from NWIS. \\
\hline \multicolumn{4}{|c|}{ SF Bay at Dumbarton Bridge, 373015122071000} \\
\hline Turbidity, SSC & Mid-depth & 1993-present & $\begin{array}{l}\text { Station temporarily discontinued because of bridge construction } \\
\text { October 1, 2011-March 16, } 2013 \text {. }\end{array}$ \\
\hline Turbidity, SSC, DO & Near-bottom & 1993-present & Data are downloaded hourly by using cellular telemetry. \\
\hline $\mathrm{SSC}$ & Cross-section & 2009-present & \\
\hline Q, SSF & Cross-section & 2009-present & Q and SSF data are not yet available from NWIS. \\
\hline \multicolumn{4}{|c|}{ SF Bay at San Mateo Bridge near Foster City, 11162765} \\
\hline $\mathrm{SpC}, \mathrm{T}$ & Near-surface & 1989-present & $\begin{array}{l}\text { Turbidity and SSC collected from } 1993 \text { to } 2005 . \\
\text { Data are downloaded hourly by using cellular telemetry. }\end{array}$ \\
\hline $\mathrm{SpC}, \mathrm{T}, \mathrm{DO}$ & Near-bottom & 1989-present & \\
\hline \multicolumn{4}{|c|}{ SF Bay at Alcatraz Island, 374938122251801} \\
\hline $\mathrm{SpC}, \mathrm{T}$, turbidity, SSC & Mid-depth & 2003-present & Data are downloaded hourly by using cellular telemetry. \\
\hline \multicolumn{4}{|c|}{ Corte Madera Creek near Larkspur, 11460090} \\
\hline $\mathrm{SpC}, \mathrm{T}$, turbidity, SSC, DO & Mid-depth & 2010-2013 & Station discontinued October 31, 2013 \\
\hline $\mathrm{SSC}$ & Cross-section & $2010-2013$ & - \\
\hline Q, SSF & Cross-section & $2010-2013$ & Q and SSF data are not yet available from NWIS. \\
\hline
\end{tabular}


Table 1. Continuous water-quality monitoring stations, Suisun Bay, San Pablo Bay, and Central and South San Francisco Bays, California, October 1, 2010-September 30, 2013.-Continued

[Abbreviations: SF, San Francisco; SpC, specific conductance; T, water temperature; SSC, suspended-sediment concentration; DO, dissolved oxygen; Q, water discharge; SSF, suspended-sediment flux; NWIS, National Water Inventory System; - , not applicable]

\begin{tabular}{|c|c|c|c|}
\hline Water-quality parameter & $\begin{array}{l}\text { Measurement } \\
\text { location }\end{array}$ & Period of record & Remarks \\
\hline \multicolumn{4}{|c|}{ SF Bay at Richmond/San Rafael Bridge, 375607122264701} \\
\hline $\mathrm{SpC}, \mathrm{T}$, turbidity, SSC & Mid-depth & 2006-present & - \\
\hline $\mathrm{SpC}, \mathrm{T}$, turbidity, SSC, DO & Near-bottom & 2006-present & - \\
\hline \multicolumn{4}{|c|}{ Carquinez Strait at Carquinez Bridge, 11455820} \\
\hline $\mathrm{SpC}, \mathrm{T}$ & Mid-depth & 1998-present & Turbidity and SSC collected from 1998 to 2005 \\
\hline $\mathrm{SpC}, \mathrm{T}$ & Near-bottom & 1999-present & \\
\hline \multicolumn{4}{|c|}{ Suisun Bay at Benicia Bridge, 11455780} \\
\hline $\mathrm{SpC}, \mathrm{T}$, turbidity, SSC & Near-surface & 2001-present & - \\
\hline SpC, T, turbidity, SSC, DO & Near-bottom & 2001-present & - \\
\hline \multicolumn{4}{|c|}{ Suisun Bay at Mallard Island, 11185185} \\
\hline Turbidity, SSC & Near-surface & 1994-present & $\begin{array}{l}\text { Near-surface sensor attached to a float to maintain a constant depth } \\
\text { below water surface of } 3.3 \mathrm{ft} \text {. }\end{array}$ \\
\hline Turbidity, SSC & Near-bottom & 1994-present & Data are downloaded hourly by using cellular telemetry. \\
\hline
\end{tabular}

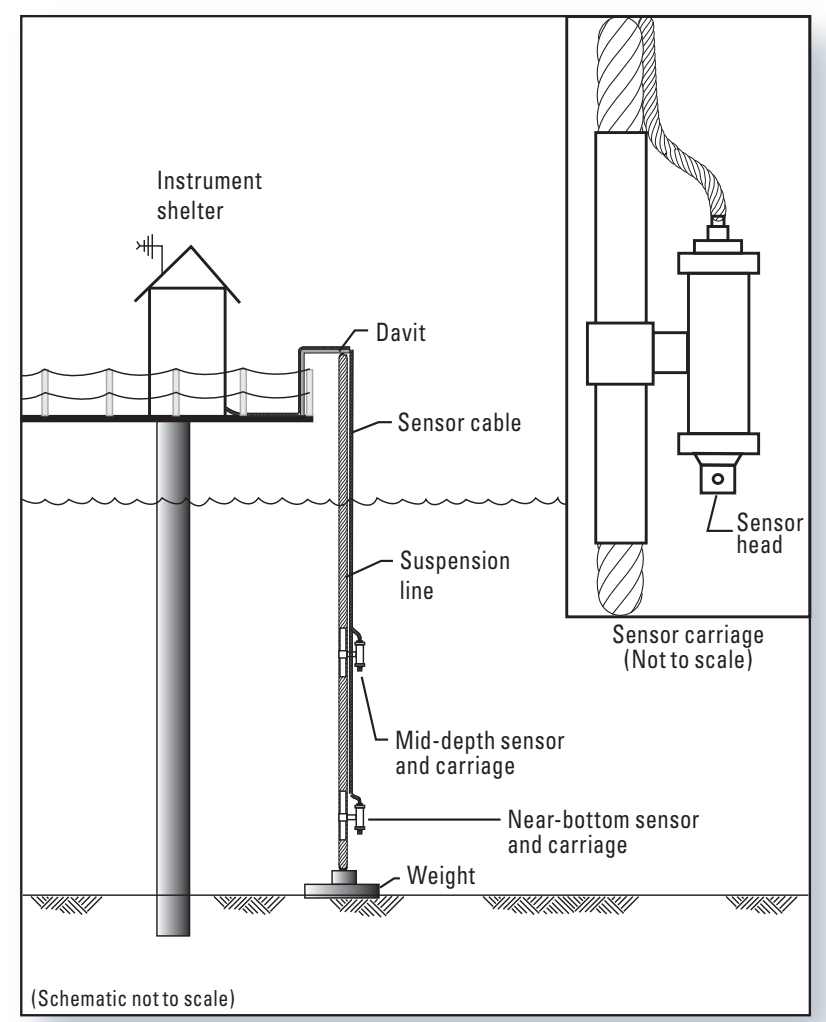

Figure 2. Typical monitoring installation, San Francisco Bay study.

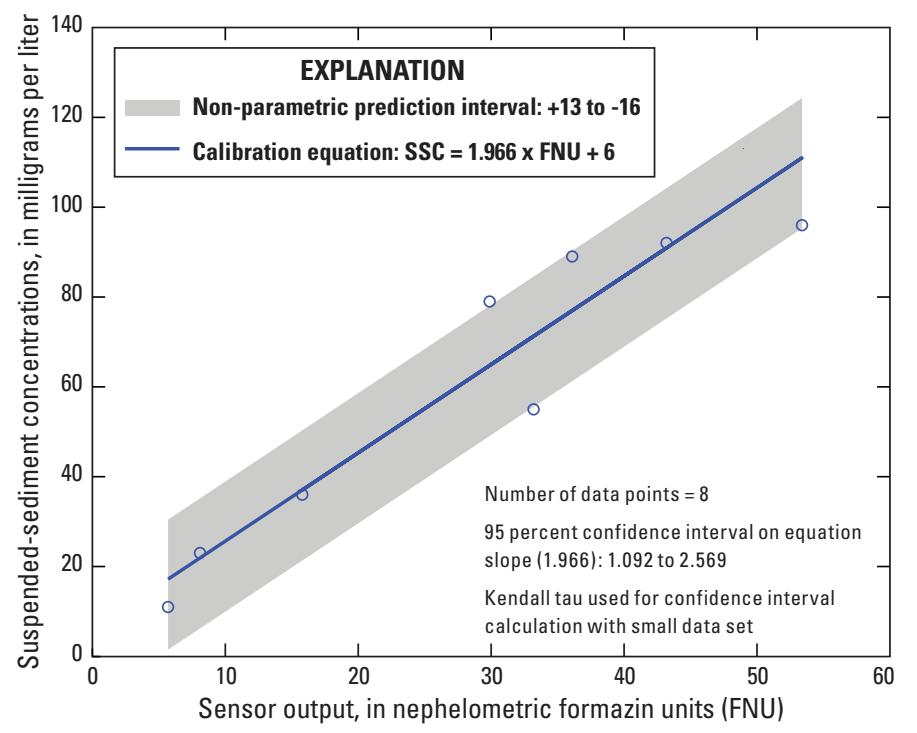

Figure 3. Example calibration curve that relates turbidity to suspended-sediment concentrations (SSC). Output of an optical turbidity sensor is related to the SSC measured in water samples. 


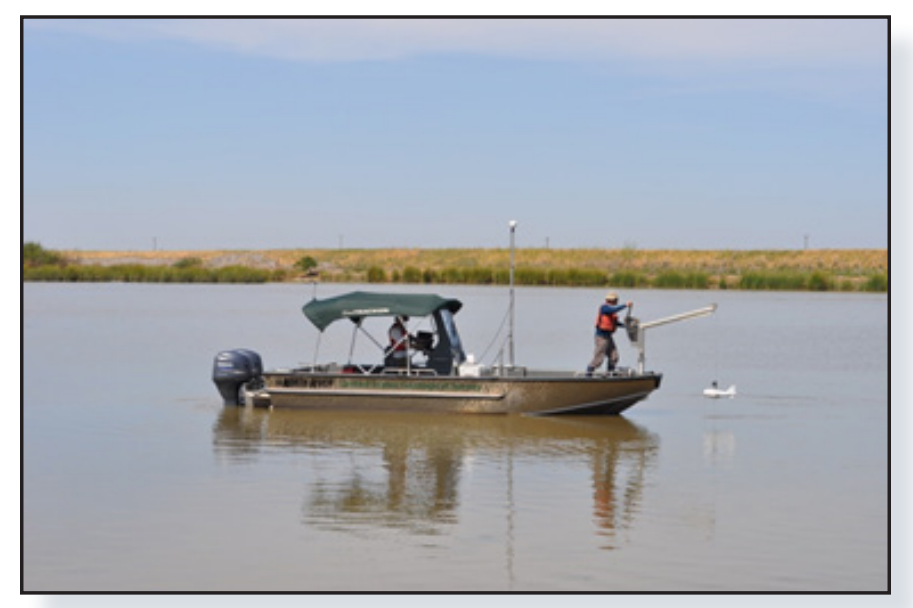

Figure 4. U.S. Geological Survey scientists collecting velocity data by using an acoustic Doppler current profiler and suspendedsediment concentration samples by using a depth-integrated sampler. Photo taken by Tara Morgan-King.

using an acoustic Doppler current profiler (fig. 4). To calculate the suspended-sediment flux, in mass per unit time, the crosssectionally averaged SSC is multiplied by the water discharge passing through the cross section. Data are reviewed and edited before final approval. Details about these methods are available at http://ca.water.usgs.gov/projects/baydelta/methods.html.

Specific-conductance, water-temperature, and turbidity data are collected at two depths in the water column to help define the vertical variability. At the shallow water sites (Alviso Slough, Alcatraz Island, and Corte Madera Creek), however, data are collected only at one depth. At the sites where dissolved oxygen is monitored, data are collected at the nearbottom position only (table 1).

\section{Instrument Specifications}

Specific conductance (reported in microsiemens per centimeter at $25^{\circ}$ Celsius) and water temperature (reported in degrees Celsius) have been measured by using a YSI, Inc., conductance/temperature sensor ${ }^{1}$ (fig. 5) Two types of optical sensors have been used to monitor turbidity: the DTS-12, manufactured by Forest Technology Systems, and the model 6136, manufactured by YSI, Inc. Dissolved oxygen has been measured by using the optical model 6150 , manufactured by YSI, Inc. Sensors manufactured by YSI, Inc., are installed on the 6920 multi-parameter water-quality logger.

${ }^{1}$ The use of firm, trade, and brand names in this report is for identification purposes only and does not constitute endorsement by the U.S. Geological Survey.

\section{For more information:}

http://ca.water.usgs.gov/projects/baydelta/

Contact: Paul Buchanan California Water Science Center 6000 J Street, Placer Hall, Sacramento, CA 95819 buchanan@usgs.gov

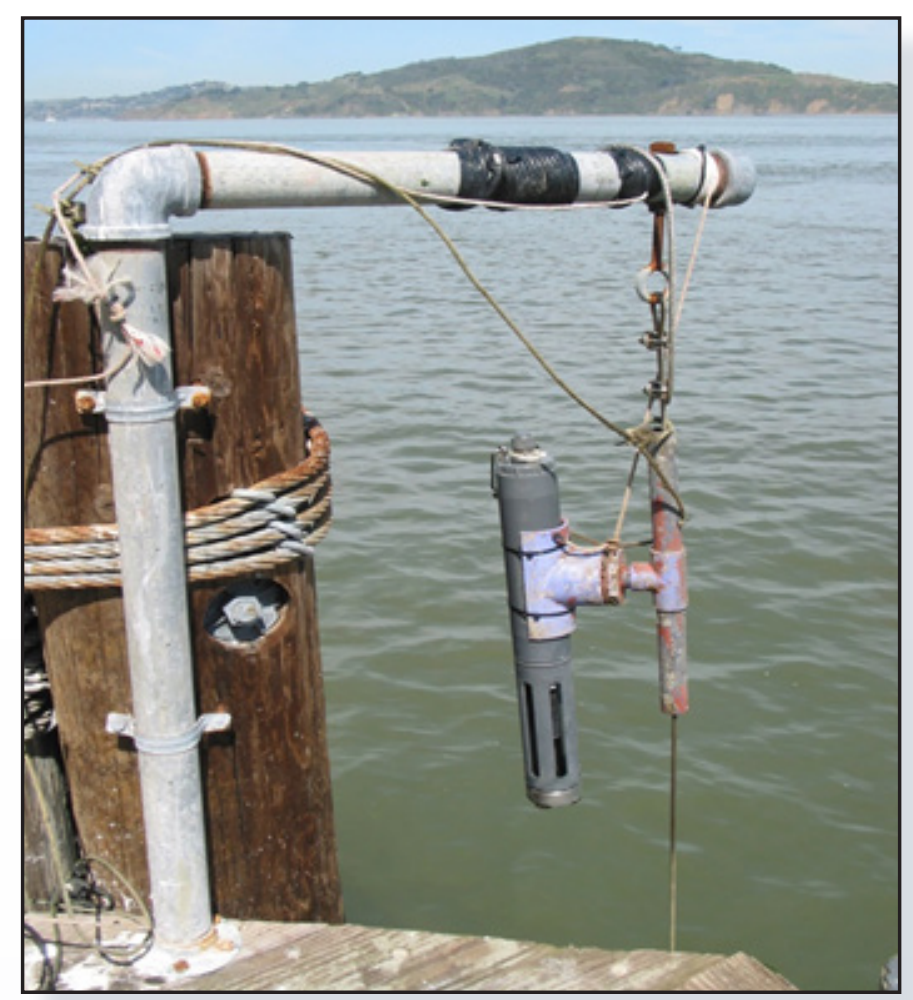

Figure 5. Water-quality instrument ready for redeployment at Alcatraz Island. Photo taken by Kurt Weidich.

In an environmental monitoring program, potential sources of introduced error include, but are not limited to, electronic drift, calibration errors, and biological fouling of sensors. Data corrections (necessary because of biological fouling or instrument electronic drift) have been applied to the affected periods of record following USGS guidelines (http://ca.water.usgs.gov/ projects/baydelta/methods.html).

Continuous water-quality and suspended-sediment transport data collected during water years 2011-13 (October 2010 to September 2013) are archived in the USGS National Water Information System and are available to the public at http://waterdata.usgs.gov/ca/nwis/nwis.

By Buchanan, P.A., Downing-Kunz, M.A., Schoellhamer, D.H., Shellenbarger, G.G., and Weidich, K.W.

\section{Acknowledgements}

Collection of these data was supported by the U.S. Army Corps of Engineers, San Francisco District, as part of the Regional Monitoring and Regional Sediment Management Programs; Interagency Ecological Program; California State Coastal Conservancy; U.S. Bureau of Reclamation; U.S. Geological Survey San Francisco Bay Pilot Study for the National Water-Quality Monitoring Network for U.S. Coastal Waters and their Tributaries, U.S. Geological Survey Priority Ecosystems Science Program; and the U.S. Geological Survey Federal/State Cooperative Program. 